\title{
Sri Lanka-China Tourism Relations An Analysis of Recent Trends in Chinese Tourist Arrivals to Sri Lanka
}

\author{
N.P.R. Deyshappriya
}

A.A.K.A. Damanupola

M. M. T. D. M. Kumari

\begin{abstract}
Tourism is widely recognised as one of the world's largest and fastest growing industries, accounting for approximately $10 \%$ of the global GDP, and employing a growing workforce of 283.5 million. In the context of Sri Lanka, the tourism sector is the 3rd largest foreign income earner and the total contribution to the economy is around $12 \%$ of GDP. This paper examines the recent trends in Chinese tourist arrivals to Sri Lanka along with the comparative position of Sri Lanka as an outbound tourism destination of China. It is observed that during the period of 1984 - 1994, Germany held the number one spot in Sri Lanka's tourist arrivals. Until 2004, Germany, India and the UK were the 'top 3' countries among Sri Lanka's tourist arrivals, and China's contribution to local tourism was insignificant. In 2014, however, China was raised to the rank of the $3^{\text {rd }}$ major tourist partner of Sri Lanka, accounting for $8.4 \%$ of total tourist arrivals. Moreover, Chinese tourist arrivals grew remarkably by $72.5 \%$ in $2010-2016$, while Indian and UK tourist arrivals increased only by $19.3 \%$ and $10.3 \%$, respectively. Furthermore, tourist arrivals from China increased by $68 \%$ in 2015 compared to 2014 , while Indian tourist arrivals grew only by $30 \%$. Despite the impressive growth rate in Chinese tourist arrivals to Sri Lanka, these numbers are negligible in comparison to Chinese outbound tourism to other countries. Even though Sri Lanka was among the top 25 tourist destinations of Chinese travellers in 2007, it no longer holds this valuable position. Thus, this study recommends promoting Sri Lankan tourism destinations, e-tourism sites, improving air-connectivity between the two countries and cultivating tourism-friendly 'soft power' by celebrating festivals such as Chinese New Year, increasing the number of Chinesespeaking guides and hotel staff and introducing Chinese-language apps for tourists in order to multiply prospective tourists from China.
\end{abstract}

Keywords: China, Sri Lanka, Soft Power, Tourism Destinations, Tourist Arrivals 


\section{Introduction}

\section{Historical Aspect of Sri Lanka Tourism}

Sri Lanka is a prominent vacation destination for centuries due to its uniqueness

and strategic positioning. This tiny beautiful island is also known as "The Pearl of the Indian Ocean", Serendib, Ceylon and "Taprobane" among the explorers and merchants for many years (SLTDA, 2011). Sri Lanka was under three main administration periods namely, Portuguese, Dutch and British from 1505 to 1815. Furthermore, it recaptured its freedom from the English in 1948. Amidst the post-freedom period, tourist fluctuations were witnessed. However, Sri Lanka is recognised as one of the prominent tourist destinations in the world (Brau et al., 2011).

At first, Sri Lanka was recognised as a renowned religious or rather, a pilgrimage tourism destination (Fernando, 2015). Later it became a famous transit for many vessels in trade and commerce due to its significant geographical positioning. At that point the Sri Lankan Government set up its first Tourist Bureau in 1937 with the primary aim of fulfilling the service requirements of these arriving travellers and sailors travelled between the West and the East (Fernando et al. 2013). Despite the fact that definite records are inaccessible in relation to the above period, it is assessed that almost one hundred thousand to two hundred thousand travellers visited the nation per annum (SLTDA, 2011). It is unfortunate to mention here that the Tourist Bureau terminated its operations in the 1940s due to World War II. During this period, tourist arrivals also became quite insignificant due to war and unsafety.

In the wake of recovering autonomy in 1948, the new legislature of Sri Lanka revamped the significance of the travel industry and built the Government Tourist Bureau under the Ministry of Commerce. As per SLTDA data (SLTDA, 2011), a range of accommodation facilities were constructed throughout the country during the British administration period. Initially, these facilities were not originally designed for the promotion of inbound tourism and it was greatly a spontaneous improvement. Later with the developing interest in the Sri Lankan travel industry these facilities were used for different tourism industry related activities. During the 1950 s, tourism became one of the rapidly emerging industries in the world due to massive developments in the transportation and infrastructure fields particularly as a result of technological development through the industrial revolution. Sri Lanka was also able to attract high tourist influx to the country during this period. However, during the period 1954 - 1960 Sri Lankan tourist arrivals demonstrated a sharp decrease because of the inadequate government help for the tourism industry (Ranasinghe \& Deyshappriya, 2011).

When going through the history of Sri Lankan tourism and the development stages, 1960 can be identified as a milestone in initiating planned tourism. In 1966, the government established an authoritative body for the tourism sector and formed the Ceylon Tourist Board under the Tourist Board Act No. 10 of 1966. The Ceylon Hotels Corporation was set-up by Act No. 14 of 1966 with the primary objective of educating and promoting skilful labour required for the Sri Lankan tourism industry. 
Thereafter, the Tourist Development Act No. 14 of 1968 was introduced. In 1966, the first Ten Year Master Plan for tourism was introduced. These inceptions were directed to an enormous advancement of the Sri Lankan travel industry. In addition, presenting an open economy approach by the legislature was another defining moment in attracting a high number of tourists to the nation. However, 1983 was a defining year regarding the high decrease in the number of arrivals to the nation due to ethnic riots that began in July 1983 and the civil war in the North and East. Amidst the first phase of the civil war (19831987), the number of tourists declined at a normal yearly rate of 15 percent. Because of the civil war, Sri Lanka was seen as an unsafe destination to travel. In May 2009, the Sri Lankan government ended the civil war that led to a huge development in the Sri Lankan travel industry.

\section{Tourism and the Sri Lankan Economy}

Presently, the tourism industry plays a vital role in Sri Lanka's economy especially in terms of foreign exchange earnings. Tourism is one of the top ten largest sources of Foreign Exchange, and it takes the $3^{\text {rd }}$ rank in the Sri Lankan economy. In 2017, the contribution of travel and tourism to the GDP for Sri Lanka was 9.9 billion US dollars. Between 1998 and 2017, the contribution of travel and tourism to the GDP of Sri Lanka grew substantially from 1.1 to 9.9 billion US dollars rising at an increasing annual rate that reached a maximum of $32.97 \%$ in 2002 and then decreased to $3.96 \%$ in 2017 as depicted in figure 01 . Nevertheless, with the post war tourism boom in the country, the Sri Lankan tourism industry had the capacity to draw in a huge number of visitors to the nation while contributing intensely to the national economy. However, Sri Lanka is comparatively at a lower level than regional competitors such as the Maldives (78.1\%), Thailand (19.3\%) and Malaysia (14.9\%) in terms of each country's tourism sector's share of GDP.

Figure 01: Contribution of Travel \& Tourism to GDP of Sri Lanka

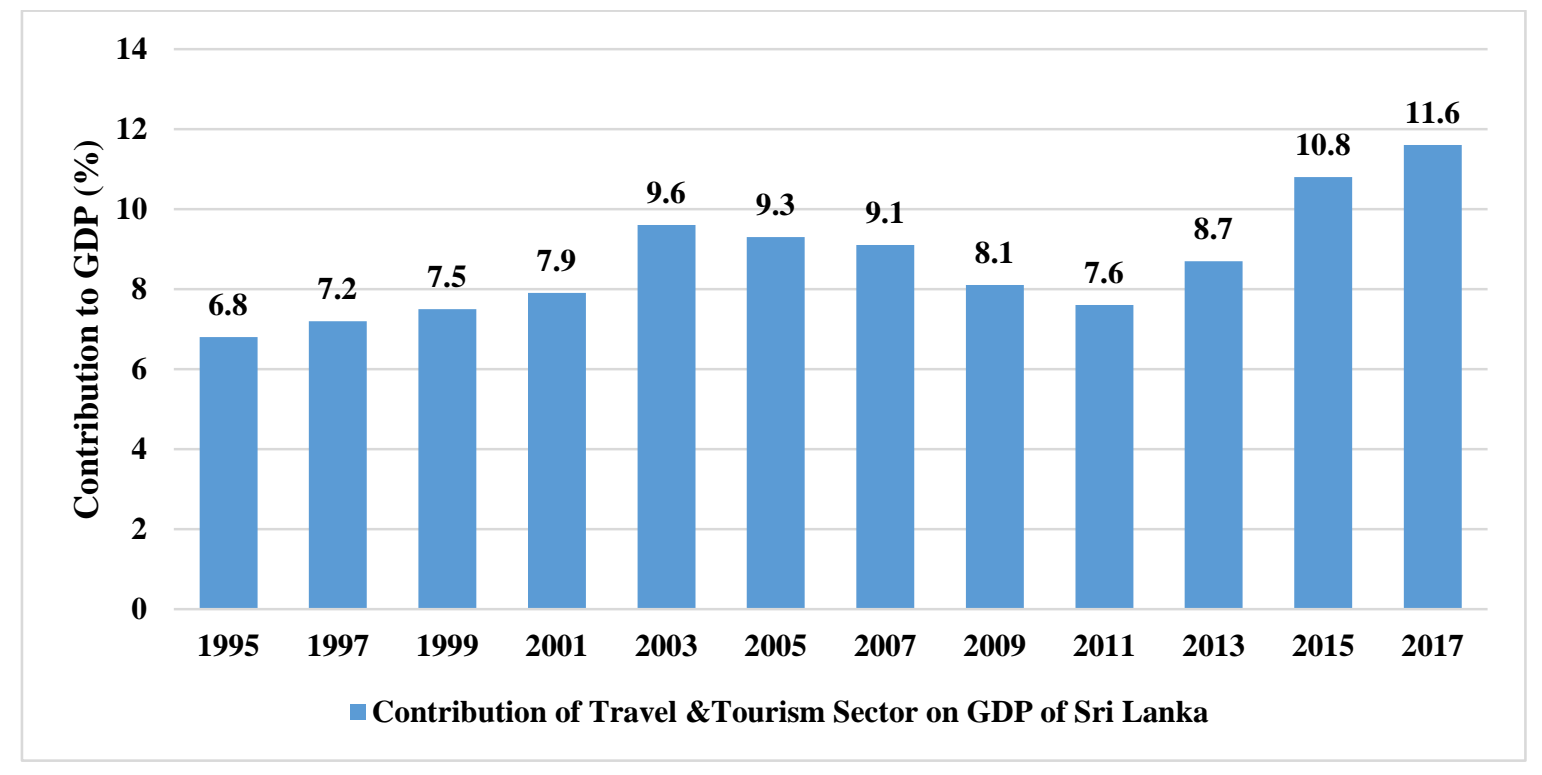

Source: Created by authors based on World Travel and Tourism Council 
As depicted in figure 01, from 1991- 2001 the Sri Lankan tourism industry heavily relied on Western European markets, especially the United Kingdom and Germany as main sources of foreign tourist markets. However, that trend began to change from 2002, as India became the largest single source of arrivals in Sri Lanka (Central Bank, 2007). During this period China, Japan, France, Maldives, Australia, and the Netherlands also became strong markets.

As a source of foreign income generator, Sri Lanka earned over 213 million US dollars in 2001 from direct tourist sector services and increased up to 350 million US dollars in 2009 and 575 million US dollars in 2010 and 645 million US dollars in 2011. The Sri Lankan tourism sector survived in 2001 with 414 hotels which included 13,626 room facilities. This environment increased to 783 accommodations with 14,714 rooms in 2010. This development helped boost the country's economy as well as in the provisions of food, spa services and other essential facilities to tourists, whilst contributing to the development of all these sectors during the past few years.

Figure 02: Contribution of Travel \& Tourism to Employment of Sri Lanka

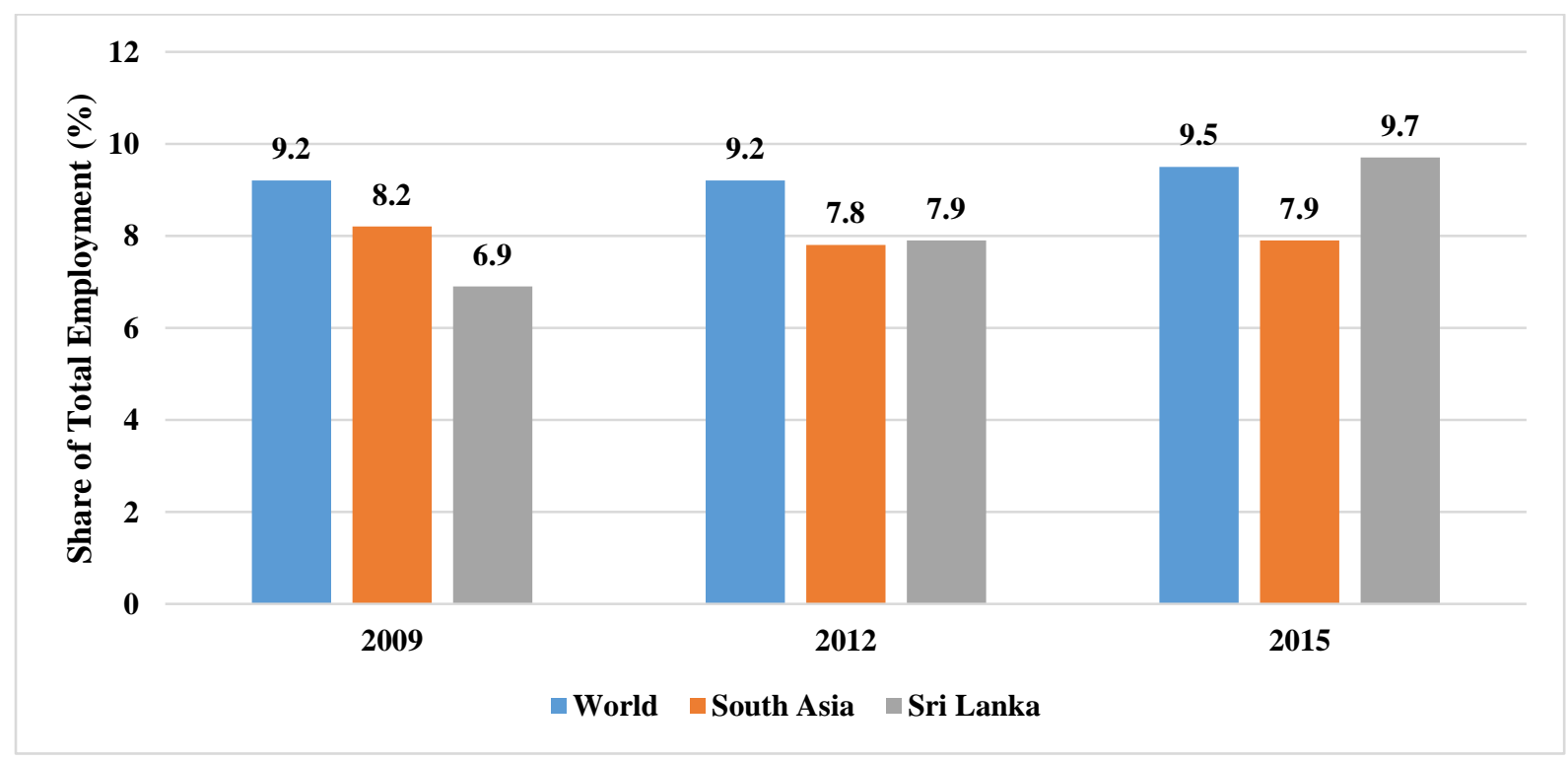

Source: Created by authors based on World Travel and Tourism Council

The rapid boom in the tourism sector had created 819,500 employment opportunities (both direct and indirect) in 2014, which was $10.0 \%$ of total employment in Sri Lanka, and is expected to increase to 943,000 by 2025 . As indicated in figure 6 , the tourism sector accounted for $9.7 \%$ of the total employment in Sri Lanka in 2015, which is higher than the corresponding percentages in the world $(9.5 \%)$ and South Asia (7.98\%). Notably, the growth of employment in the tourism sector has dramatically increased, from $6.32 \%$ in 2009 , to $5.28 \%$ and $6.44 \%$ by 2012 and 2015 , respectively. Since tourism has been a rapidly 
growing industry in Sri Lanka it is important to recognize the major tourism partners of Sri Lanka and the patterns of tourist arrivals related to them.

\section{Objectives and Structure Study}

It is a well-known fact that both political and economic ties between Sri Lanka and China have grown during the last decade. These political and economic ties have led to attract more tourists from China and therefore it is crucial to examine the significance of China as a major tourism partner of Sri Lanka. Hence, the main objective of this study is to examine the recent trends in Chinese tourist arrivals to Sri Lanka along with the comparative position of Sri Lanka as an outbound tourism destination of China.

\section{Literature Review}

According to the World Travel \& Tourism Council (WTTC), tourism is explained as travelling to and staying in a place other than a usual living environment for the purposes of leisure, business or for any other activities. The contribution of the tourism sector on economic growth, employment and rural sector development has been widely examined and well documented. Similarly, the tourism sector has been recognized as one of the new drivers of economic growth especially in many developing countries. Moreover, Wanhill \& Stephen (1983) recognized tourism as a remedy for exchange rate fluctuations, a deficit in the current account and also a higher level of unemployment. Similarly, Hazari \& Sgro (1995) included tourism as an added variable for their economic growth model. Similarly, Hazari \& Sgro (1995) observed that both supply of foreign capital and growth in export as a function of tourism growth. Apart from this, they highlight that, factors such as geography, water, vegetation and also man-made creations are highly important for a country to be promoted as a tourism destination. More specifically, the Seychelles and the Maldives are inland and they are rich in Sun, Sea and Sand while countries like Malaysia, Thailand and Kenya are rich in Culture, Nature and Adventure respectively. As the IMF (2009) indicates, the economy of such countries mainly depend on tourism and there is a specific contribution of tourism on the GDP of the Seychelles and the Maldives as $73 \%$ and $60 \%$ respectively. In fact, international tourists bring large sums of foreign currency to host countries allowing the host countries to smoothen the processes related to international finance. As McCatty \& Serju (2006) highlights, Tourism is one of the top five export categories to $r$ as many as $83 \%$ of countries and it is a main source of foreign exchange earnings for at least $38 \%$ of countries.

An empirical study by Sak \& Karymshakov (2012) investigated the causal relationship between tourism revenue and the GDP of 135 countries over the period of 1995-2008. This panel data analysis highlighted that there is a bi-directional causality between tourism receipts and GDP especially in countries located in Europe, North America, Latin America and the Caribbean regions. Apart from that, Aktar et al (2014), based on the Cointegration techniques, observed that there is a long run relationship between tourism revenue and foreign exchange earnings. It is observed that, a large number of empirical studies have examined the impact of the tourism sector on economic growth, employment and also the negative and 
positive impacts of tourism in relation to society and culture. However, studies that focus on bilateral tourism relations between particular countries are extremely rare. Despite the growing importance of China as a tourism partner of Sri Lanka over time, there is a huge gap in terms of knowledge and empirical aspects, that are needed to be filled by an empirical study. Thus, the current study is designed to address the aforementioned gap while providing timely important policy recommendations to strengthen bilateral tourism relations between China and Sri Lanka.

\section{Methodology}

\section{Data}

The study is mainly based on secondary data collected from the Sri Lanka Tourism Development Authority (SLTDA), the Central Bank of Sri Lanka and the World Travel \& Tourism Council (WTTC). In addition, the study contains data collected from several empirical studies conducted by different scholars. Moreover, data related to a number of variables such as tourist arrivals, the number of employment generated by the tourism sector and the tourism sector's contribution to the GDP were collected during the period from 1981-2017.

\section{Methods}

The current study employed descriptive analytical techniques in order to accomplish the objectives of the research. Specifically, graphical illustrations, and the calculation of growth rate and shares were utilized to emphasize the relevant facts and figures.

\section{Results and Discussion}

\section{Evolutions of Sri Lanka's Top Tourism Partners}

Due to its strategic position, exciting tourist attractions, the warm hospitality of its people, Sri Lanka attracts a significant number of tourists from all over the world. Consequently, the tourism sector has been identified as a major driver of the economic growth of Sri Lanka. In 2014, the tourism sector of Sri Lanka earned US\$2431.1 million in tourism receipts and created 129,790 and 170,000 direct and indirect employment opportunities, respectively. Sri Lanka expects to attract four million tourists by 2020 , and also plans to be a major tourism hub in the world by 2025. Under this scenario, it is important to examine the evolution of Sri Lanka's top tourism partners. Figure 03 illustrates the share of tourist arrivals from the top three countries during the period 1984-2015. 


\section{Figure 03: Sri Lanka's top tourism partners}

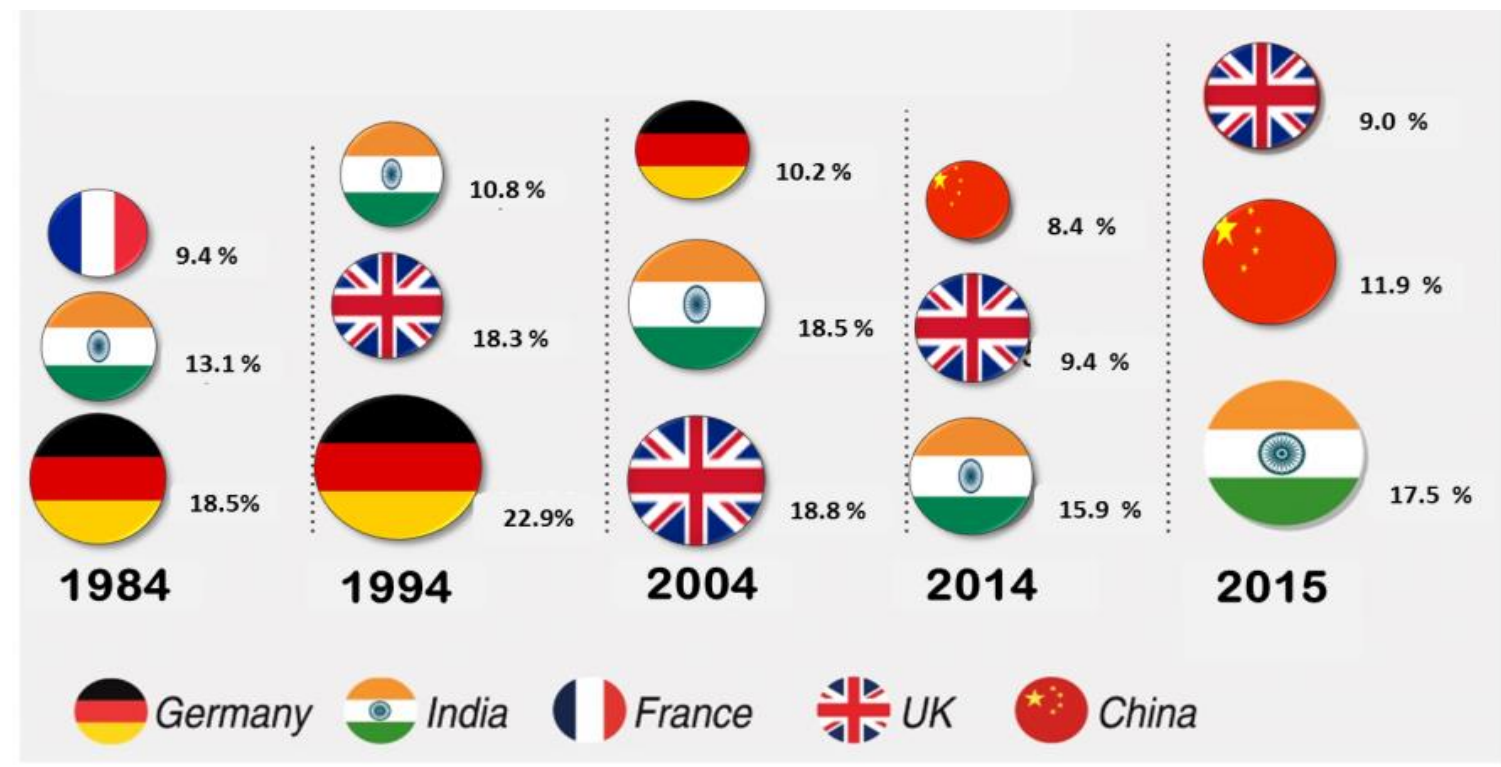

Source - Created by authors based on WTTC

In the period 1984 - 1994, Germany held the number one position in Sri Lanka's tourist arrivals. More specifically Germany accounted for $18.5 \%$ of total tourists' arrivals in 1984 , which increased to $22.9 \%$ by 1994. While, Germany dominated tourists arrivals in 1985, India reported the second highest share (13.1\%) followed by France (9.4\%). However, the share of tourist arrivals from India dropped slightly to $10.8 \%$ by 1994 and the UK had become the second largest tourism partner in Sri Lanka accounting for $18.3 \%$ of total tourist arrivals to Sri Lanka. In fact, until 2004, Germany, India and the UK were the 'top 3' countries among Sri Lanka's tourist arrivals, and China's contribution to local tourism was insignificant.

In 2014, however, China was raised to the rank of Sri Lanka's 3rd major tourist partner, accounting for $8.4 \%$ of total tourist arrivals. It climbed another notch in 2015, nudging out the UK to claim 2nd position. The main reasons for this increase were intense advertising campaigns launched in China by the Sri Lankan government, greater engagement with the Chinese media, the peaceful environment in Sri Lanka, and the strengthening of political ties between the two countries. Since 1984, India has been among the top 3 sources of tourists to Sri Lanka and India was the largest tourism partner of Sri Lanka reporting $17.5 \%$ of total tourist arrivals to Sri Lanka. It recently claimed the number one spot, but the sharp rise in Chinese tourist arrivals could change this situation in the near future. 


\section{China as a Growing Tourism Partner of Sri Lanka}

Figure 03 clearly depicts the major tourism partners of Sri Lanka during the period of 1984-2015 and also the evolution of China as a major tourism partner of Sri Lanka. Since, it is an apparent fact that China has been becoming a crucial tourism partner of Sri Lanka, it is worthwhile to examine the growing pattern of Chinese tourist arrivals to Sri Lanka. Figure 04 presents both the number and growth rate of tourists from the major source countries, in the five-year period of 2010-2016. While the largest number of tourists in that period came from India and the UK, in that order, the number of Chinese tourist arrivals increased dramatically after 2013.

Figure 04: Tourist Arrivals and Growth Rate of Tourist Arrivals from Top Five Countries (2010-2016)

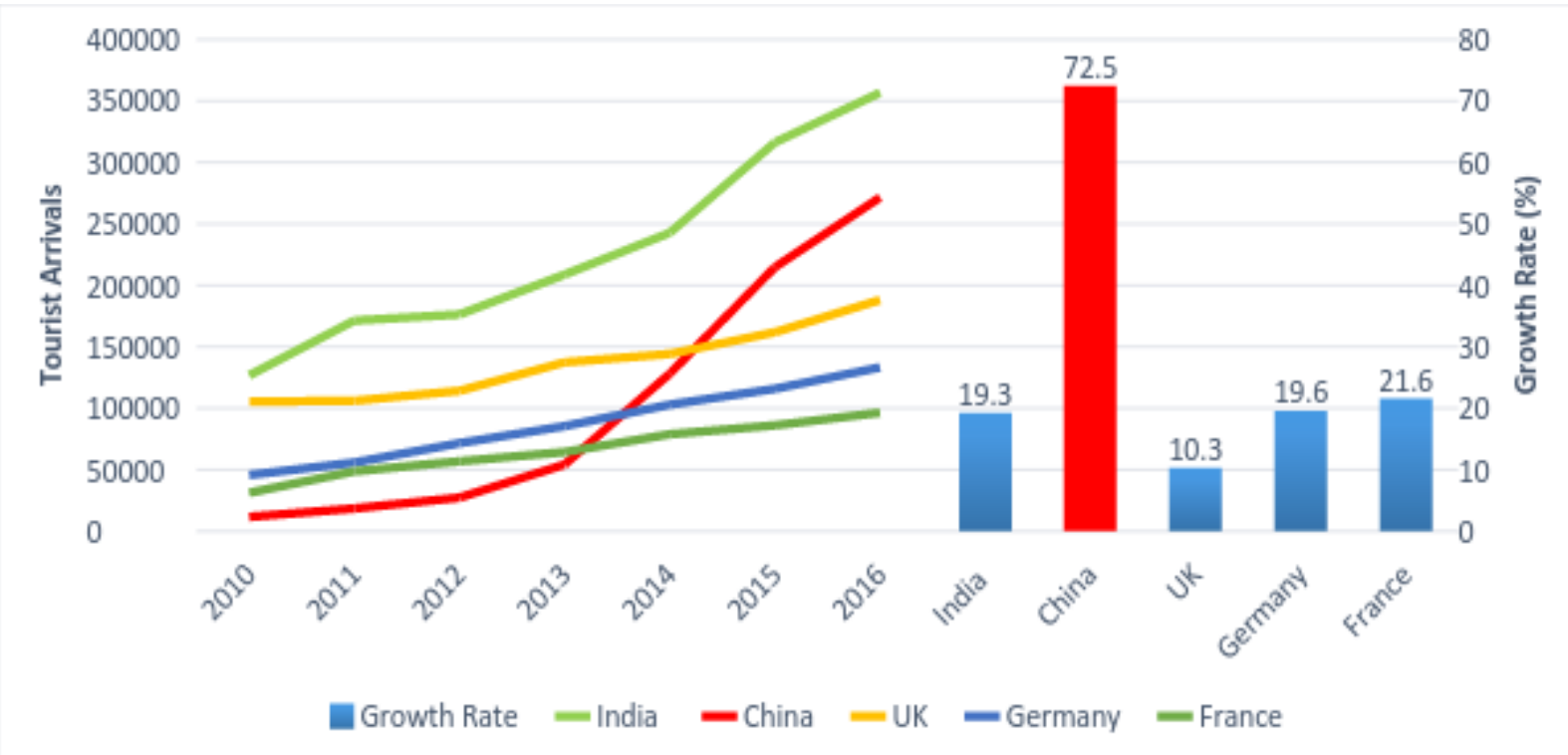

Source: Created by author, based on data from the Sri Lanka Tourism Development Authority.

Apart from the number of tourist arrivals, the growth rate of tourist arrivals shows the potential significance of China as a tourism partner of Sri Lanka. As figure 04 depicts, Chinese tourist arrivals grew remarkably by $72.5 \%$ in $2010-2016$, while Indian and UK tourist arrivals increased only by $19.3 \%$ and $10.3 \%$, respectively. Furthermore, tourist arrivals from China increased by $68 \%$ in 2015 compared to 2014, while Indian tourist arrivals grew only by $30 \%$. The above trends indicate that, there is a high possibility that China will become the top tourist partner of Sri Lanka in the near future, thereby relegating India to the second position. The growing trade and investment relations between China and Sri Lanka can also create ample opportunities for the expansion of tourist arrivals from China. Particularly, a massive promotional campaign which was conducted by the Sri Lanka Tourism Promotion Bureau in China in 2013 was the key driving force of this surge. As Sim (2014) indicated, 
"Booming Chinese tourist numbers are inseparable with the vigorous promotional drive carried out in the Chinese market and the creative activities in 2013. The tourism board, together with the Embassy of Sri Lanka, started a six-month advertising campaign beginning in September 2013 on 200 public buses in Beijing, Shanghai, Guangzhou, and Chengdu.... The gaming and resort industries are also doing their best to attract Chinese travellers to Sri Lanka". (Sim, 2014)

\section{How popular is Sri Lanka among Chinese tourists?}

With a rising middle class, China's outbound tourism market has grown exponentially. An expanded network of international flights, more convenient travel and visa procedures for Chinese citizens, and summer holiday packages provided by travel agents, are among the factors that have encouraged the growth of Chinese tourists. China is now one of the largest outbound tourism markets in the world. In 2015, it had 120 million outbound tourists travel internationally, spending approximately US $\$ 104.5$ billion. Sri Lanka has benefited considerably from the expanded outbound tourism of China, given that China is currently the second-highest source of tourist arrivals to Sri Lanka and Chinese tourists who visited Sri Lanka during $2010-2015$ increased by $17.4 \%$.

\section{Chinese tourism: Sri Lanka compared to other destinations}

Although Chinese tourist arrivals are now crucial in Sri Lanka's tourist market, it is notable that current Chinese tourist arrivals to Sri Lanka are negligible when compared to other Asian countries. Sri Lanka does not currently even rank among the top 25 tourist destinations of China. According to table 01 below, China's top tourist destinations include Hong Kong, Macau and South Korea, with these three destinations accounting for $41.05 \%, 25.7 \%$ and $4.33 \%$ of the total outbound tourism of China respectively, in 2013. The share of Chinese tourist arrivals to Sri Lanka is just $0.06 \%$ of the country's total outbound tourists, and it is significantly lower than the number of outbound Chinese tourists to other Asian countries. More specifically, the number of Chinese tourist arrivals to South Korea and Thailand are 78 and 74 times higher, respectively, than that to Sri Lanka, and the Maldives also receives more than 5 times the number of Chinese visitors than Sri Lanka.

Chinese outbound tourists to other Asian countries have also increased significantly in recent years. During the first ten months of 2014, Asian countries such as South Korea, Thailand, Taiwan, Japan, Vietnam, Malaysia and Singapore welcomed approximately 85.42 million Chinese tourists. This is apparent from the data presented in Table 01. The principle factors that have induced Chinese tourists to visit nearby destinations such as Hong Kong, Thailand, South Korea and Japan are short distances and lower travelling cost and relatively less cultural and climatic differences. Nevertheless, Chinese tourist arrivals to Sri Lanka have grown rapidly and in 2013, arrivals increased by $99 \%$, reporting the largest growth rate of Chinese tourist arrivals across the regions. It is a positive signal for Sri Lanka, and if the 
growth rate continues, there is a higher possibility of increasing Sri Lanka's share of Chinese outbound tourism.

Table 01: Chinese Outbound Tourism in 2013

\begin{tabular}{llrrr}
\hline Rank & Destination & $\begin{array}{r}\text { Number of Chinese } \\
\text { Mainland Tourists }\end{array}$ & $\begin{array}{r}\text { Share of Chinese } \\
\text { Tourists } \\
\text { per Destination }\end{array}$ & Growth (\%)(2013) \\
\hline $\mathbf{1}$ & Hong Kong & 40303300 & 41.05 & 15.3 \\
$\mathbf{2}$ & Macau & 25239400 & 25.70 & 17.4 \\
$\mathbf{3}$ & South Korea & 4253400 & 4.33 & 42 \\
$\mathbf{4}$ & Thailand & 4010300 & 4.08 & 78.7 \\
$\mathbf{5}$ & Taiwan & 2918900 & 2.97 & 11 \\
$\mathbf{7}$ & Japan & 1834600 & 1.87 & -6.5 \\
$\mathbf{8}$ & Vietnam & 1772700 & 1.81 & 32.3 \\
$\mathbf{9}$ & Cambodia & 1690600 & 1.72 & -8.4 \\
$\mathbf{1 0}$ & Malaysia & 1351600 & 1.38 & -1.5 \\
$\mathbf{1 1}$ & Singapore & 1322800 & 1.35 & 13.4 \\
$\mathbf{1 3}$ & Russia & 915300 & 0.93 & 5.3 \\
$\mathbf{1 4}$ & Indonesia & 879200 & 0.90 & 23.2 \\
$\mathbf{1 6}$ & Myanmar & 561300 & 0.57 & 2.8 \\
$\mathbf{2 3}$ & Maldives & 302400 & 0.31 & 45.1 \\
$\mathbf{N} / \mathbf{A}$ & Sri Lanka & 54288 & 0.06 & 99 \\
\hline
\end{tabular}

Source: Created by authors based on the data from the Sri Lanka Tourism Development Authority and www. travelchinaguide.com

With the prevailing peaceful environment in Sri Lanka, it would be an opportune time to implement appropriate policies to attract more Chinese tourists. Most Chinese tourists prefer destinations where they can use their own language, and they face language difficulties during their travels to South Asian countries. It is therefore essential to have more Chinese-speaking guides and hotel staff.

Similarly, most Chinese tourists use internet based online e-tourism sites such as Tuniu, Baidu and Sina to search for their preferred destinations. It is thereby necessary to promote Sri Lanka's tourism destinations, hotels, and other tourism-related information through these search engines. At the same 
time, Sri Lankan travel websites should be highly ranked on these sites to attract high-end Chinese tourists.

Sri Lanka already has a more user-friendly visa system for Chinese visitors. The national carrier, "Sri Lankan Airlines," flies three times a week to China, and a few Chinese airlines also fly to Sri Lanka. However, air-connectivity between the two countries should be further improved to provide more frequent, efficient, and convenient services. Moreover, Chinese credit cards should be accepted in Sri Lanka and there should be proper policies to foster excellent service for their consumption and payment. The prices of goods and services relating to the tourism sector should be determined collectively by the government and companies involved in the business, after considering both quality and regional price levels (Jayasundera, 2016). Given the historically good diplomatic relations between the two countries, the adoption of the above-mentioned recommendations should ensure well-developed tourism relations between the two countries

\section{Conclusions and Recommendations}

China has clearly emerged as one of the major tourist partners of Sri Lanka. It became the second-best tourist partner of Sri Lanka in terms of tourist arrivals by 2015, pushing the UK into the third position. Although India has alternatively been the top and second-best tourist partner of Sri Lanka in terms of the number of tourist arrivals, a growth rate of Chinese tourist arrivals in recent years indicates the significance and potential further growth of China as a tourism partner of Sri Lanka.

The potential for growth in the China - Sri Lanka tourism sphere is underscored by the comparative regional analysis undertaken in this paper. While Chinese tourist arrivals already play a crucial role in Sri Lanka's tourist market, the number of current Chinese tourist arrivals to Sri Lanka is negligible compared to other Asian countries. Sri Lanka does not currently rank even among the top 25 tourist destinations of China. The share of Chinese tourist arrivals to Sri Lanka is just $0.06 \%$ of the country's total outbound tourists, which is drastically low compared to the number of outbound Chinese tourists to other Asian countries.

With the prevailing peaceful environment in Sri Lanka and a growing middle class in China, this is an opportune time to implement appropriate policies to attract more Chinese tourists. Sri Lanka should introduce new policies and practices to strengthen the tourism sector. The following are just some of the positive steps that can be taken in order to attract more Chinese tourists. Mainly, it is crucial to increase the number of Chinese-speaking guides and hotel staff to avoid language related difficulties faced by the tourists. Similarly, Chinese-language apps should be introduced for the increasing numbers of Chinese tourists traveling outside a tour group. These apps would help Chinese tourists navigate Sri Lanka's main destinations. They could include maps, restaurants, historical sights, tourists' reviews and experiences, and could also generate revenue via advertising. Apart from that it is important to promote Sri Lanka's 
tourism destinations, hotels, and other tourism-related information on Chinese e-tourism sites such as Tuniu, Baidu and Sina, and also on Chinese social media, especially Weibo.

In terms of air connectivity, it is strongly recommended to improve air-connectivity between the two countries. Sri Lankan Airlines currently flies fifteen times a week to different destinations (Beijing, Shanghai, Kunming and Guangzhou) in China, and three Chinese airlines (Air China, China Eastern and China Airlines) also fly to Sri Lanka. By contrast, Thai Airways operates fourteen flights per week between Bangkok and Shanghai. Shopping has been recognized as one of the key drivers for Chinese tourists when selecting travel destinations. In 2015, Chinese tourists spent US $\$ 200$ billion (which is estimated to increase up to US $\$ 450$ billion by 2025) on shopping, accounting for $30 \%$ of total overseas spending in 2015. (Kawano et al., 2015). Thus, world-class shopping complexes should be established in tourism destinations in order to satisfy the growing demand for shopping. Finally, it is recommended to cultivate tourism-friendly 'soft power' by recognising and celebrating festivals such as Chinese New Year, which are increasingly global. In a similar vein, organising creative, crowd-friendly events such as a Chinese 'street food' fair and a Dragon Boat Festival, which, signal Sri Lanka's receptiveness to Chinese culture.

\section{References}

Aktar, M.A., Sadekin, M.N, and Saha, S. K. (2014). Relationship between tourist arrival and foreign exchange earnings: The case for Bangladesh. Mediterranean Journal of Social Sciences, 5 (16).

Brau, R., Di Liberto, A., \& Pigliaru, F. (2011). Tourism and development: A recent phenomen built on old (Institutional) roots? The World Economy, 34(3),

Central Bank (2007). Annual Report. Central Bank of Sri Lanka

Fernando, S. (2015). Tourism in Sri Lanka and a computable general equilibrium (CGE) analysis of the effects of post-war tourism boom. (Unpublished Ph.D Thesis), Griffith University, Griffith Bussines School.

Fernando, S., Bandara, J. S., Liyanaarachch, S., Jayathilaka, R., \& Smith, C. (2013). Political violence and volatility in international tourist arrivals: the case of Sri Lanka. Tourism Analysis, 18(5), 575-586.

Hazari, B.R. and Sgro, P.M. (1995). Tourism and Growth in a Dynamic Model of Trade. Journal of International and Economic Development. 4, 243-252.

IMF (2009). Annual Report: Fighting the Global Crisis. International Monetary Fund

Jayasundera, D. (2016). China unhappy with legal framework for large, scale investments. Daily Financial Times, September 16.

Kawano, S., Joshua, L. Ricky, T. and Jingyuan, L. (2015). The Chinese Tourist Boom. The Asian Consumer.

Machel McCatty \& Prudence Serju. (2006) Touris, Economic Growth \& Employment, Bank of Jamaica.

Ranasinghe R., and Deyshappriya R. (2012). Analysing the significance of tourism on Sri Lankan economy. International Conference on Business and Information, Kelaniya University of Sri Lanka.

Sak, N., \& Karymshakov, K. (2012). Relationship between tourism and economic growth: A panel Granger causality approach. Asian economic and financial review, 2(5), 591.

Sim, S. (2014). Sri Lanka Sees 136 Percent Surge In Chinese Tourist Arrivals. Jing Daily

SLTDA. (2011). Annual statistical report of Sri Lanka tourism.

Wanhill and Stephen R. (1983). Measuring the Economic Impact of Tourism. Service Industries Journal. 3, 9-20

$60 \mid$ P a g e 